\title{
BRCA1 expression serves a role in vincristine resistance in colon cancer cells
}

\author{
ZHONGJIE $\mathrm{XU}^{1,2}$ and LIRONG ZHANG ${ }^{1}$ \\ ${ }^{1}$ School of Basic Medical Sciences, Zhengzhou University, Zhengzhou, Henan 450001; \\ ${ }^{2}$ Department of Life Sciences and Technology, Xinxiang Medical University, Xinxiang, Henan 453003, P.R. China
}

Received March 25, 2016; Accepted February 13, 2017

DOI: $10.3892 / \mathrm{ol} .2017 .6149$

\begin{abstract}
The present study aimed to investigate the association between breast cancer susceptibility gene 1 (BRCA1) expression and drug resistance in colon cancer, with the specific aim of elucidating the underlying molecular mechanisms of vincristine (VCR) resistance in tumor cells. The HCT-8 human colon cancer cell line was used to establish the VCR-resistant HCT-8/V line by gradually increasing the concentration of VCR during cell culture. The relative mRNA and protein expression levels of BRCA1 in these colon cancer cell lines was assessed by reverse transcriptase-quantitative polymerase chain reaction (RT-qPCR) analysis and western blotting, respectively. Resistance to VCR was established in the HCT-8/V colon cancer cells, and RT-qPCR and western blot analysis revealed the expression of BRCA1 to be significantly higher in the VCR-resistant cells compared with their drug-sensitive counterparts $(\mathrm{P}<0.05)$. The decreased BRCA1 expression in these VCR-resistant cells may be associated with the drug resistance frequently observed in colon cancer.
\end{abstract}

\section{Introduction}

Colon cancer is one of the most common malignant tumors of the digestive system. With economic development and changes in lifestyle, the incidence of colon cancer is increasing, endangering human life and health (1). Chemotherapy is an important treatment strategy for colon cancer (2); however, it is a long process involving drug combinations and the administration of large doses of drugs. Tumor drug resistance has become increasingly frequent and is a problem for the treatment of colon cancer and other malignant tumors (3). Notably, $90 \%$ of cancer mortalities are associated with tumor drug resistance (4), therefore the underlying molecular

Correspondence to: Dr Lirong Zhang, School of Basic Medical Sciences, Zhengzhou University, 100 Science Avenue, Zhengzhou, Henan 450001, P.R. China

E-mail:xcj029@163.com

Key words: colon cancer, drug resistance, HCT-8 cells, BRCA1, vincristine mechanisms regulating the development of drug resistance are a key focus of malignant tumor research. Mechanisms of drug resistance in tumors include the modification of drug targets, repair of damaged cells, and the activation or inhibition of cell death signaling pathways. These processes can result from gene mutations, deletions or amplifications, in addition to epigenetic changes that occur via abnormal DNA methylation or the post-transcriptional regulation of microRNAs (miRNAs) (5-7).

Vincristine (VCR), the most frequently used chemotherapy drug in the clinical treatment of colon cancer, is a cell cycle-specific drug that binds to tubulin, thereby inhibiting the assembly of microtubule structures and arresting mitosis in metaphase (8). The tumor suppressor breast cancer susceptibility gene 1 (BRCA1) confers increased susceptibility to breast and ovarian cancers, and mutations in the BRCA1 gene are present in $\leq 50 \%$ of inherited breast cancers $(9,10)$. In women $<50$ years old, the risk of colorectal cancer is increased in carriers of BRCA1 mutations (11).

In the current study, the expression of BRCA1 was verified by reverse transcription-quantitative polymerase chain reaction (RT-qPCR) analysis and western blotting, to investigate the role of BRCA1 in modulating VCR resistance. The findings reported here demonstrate potential candidate targets for gene therapy in VCR-resistant colon cancer.

\section{Materials and methods}

Cell culture. Human colon cancer HCT-8 cells were purchased from the Cell Bank of the Chinese Academy of Sciences (Shanghai, China). Cells were maintained in Dulbecco's modified Eagle's medium (Sigma-Aldrich; Merck KGaA, Darmstadt, Germany) containing 10\% fetal calf serum, $100 \mu \mathrm{g} / \mathrm{ml}$ penicillin, and $100 \mu \mathrm{g} / \mathrm{ml}$ streptomycin at $37^{\circ} \mathrm{C}$ with $5 \% \mathrm{CO}_{2}$ in a humidified incubator. The cells were subcultured every 2-3 days through treatment with $0.02 \%$ EDTA and $0.1 \%$ trypsin.

Establishment of a VCR-resistant colon cancer cell line. HCT-8/V cells lines were established through culture with gradually increasing VCR concentrations. The VCR-sensitive HCT-8 cell line was cultured in medium containing $5 \mathrm{ng} / \mathrm{ml}$ VCR, following which the VCR concentration was gradually increased to $10,100,1,000$, and finally 2,000 ng/ml. At each VCR concentration, some drug resistance was acquired 
by the cells and those cells that grew well were cloned by limiting dilution for the next round of selection at a higher drug concentration. Finally, HCT-8 cells were cultured in 2,000 ng/ml VCR > 20 generations and VCR supplementation was withdrawn 1 week prior to when the cells were subjected to further experiments.

MTT assay. Cells were maintained at $37^{\circ} \mathrm{C}$ with or without VCR for 24,48 and $72 \mathrm{~h}$. MTT reagent $(5 \mathrm{mg} / \mathrm{ml})$ was added to the medium and cells were further incubated for $4 \mathrm{~h}$, following which the culture medium was removed and dimethylsulphoxide (DMSO) was added to dissolve the crystalline product that had formed. The absorbance (optical density; OD) in each well was measured using a UV visible spectrophotometric plate reader (Thermo Fisher Scientific, Inc., Waltham, MA, USA) at $490 \mathrm{~nm}$. Cell growth inhibition rates were calculated as [OD (control)-OD (experimental)/OD (control) x100\%], allowing the half-maximal inhibitory concentration $\left(\mathrm{IC}_{50}\right)$ values to be calculated from triplicate experiments.

RNA extraction and RT-qPCR analysis. Cells were collected during the exponential growth phase and total RNA was isolated using the RNeasy kit (Qiagen, Inc., Valencia, CA, USA). First strand complementary DNA was synthesized from total RNA as previously described (12). The PCR reactions were performed on an Mx3000P qPCR system (Stratagene; Agilent Technologies, Inc., Santa Clara, CA, USA) and GAPDH was used as an inter-sample control. RT-qPCR was performed as previously described (13). Primer sequence information is provided in Table I.

Western blotting. Cellular proteins were extracted with cell lysis buffer (CST Bio, Inc., Shanghai, China) containing $1 \mathrm{mM}$ phenylmethylsulfonyl fluoride. Equal amounts $(25 \mu \mathrm{g})$ of protein per lane were fractionated on a $7 \%$ gel by SDS-PAGE as previously described (14), transferred to a polyvinylidene difluoride membrane, and incubated overnight with primary antibodies against BRCA1 (B1310; 1:1,000 dilution, Sigma-Aldrich; Merck KGaA), washed and incubated for $1 \mathrm{~h}$ with $\beta$-actin (AC-74; 1:2,000 dilution, Sigma-Aldrich; Merck $\mathrm{KGaA}$ ) at room temperature. Blot signal Antibody labeling was detected by an enhanced chemiluminescence system and subsequently exposed to radiographic film. Blot signal intensities were quantified using ImageJ 1.37 software (National Institutes of Health, Bethesda, MD, USA) following normalization to the corresponding loading controls.

Statistical analysis. All statistical analyses were performed using SPSS software (version 13.0; SPSS, Inc., Chicago, IL, USA) and are expressed as the mean \pm standard deviation. A Student's t-test with SPSS 17.0 software was used for statistical analysis. $\mathrm{P}<0.05$ was considered to indicate a statistically significant difference.

\section{Results}

Establishment of VCR-resistant colon cancer cells. The VCR-resistant cell line referred to as HCT-8/V was established by gradually increasing the concentration of VCR during cell culture. The HCT-8/V cells grew well in medium
Table I. Primers used for reverse transcription-quantitative polymerase chain reaction analysis.

\begin{tabular}{llc}
\hline $\begin{array}{l}\text { Gene } \\
\text { name }\end{array}$ & \multicolumn{1}{c}{$\begin{array}{c}\text { Primer sequence } \\
\left(5^{\prime}-3^{\prime}\right)\end{array}$} & $\begin{array}{c}\text { Product } \\
\text { length (bp) }\end{array}$ \\
\hline BRCA1 & $\begin{array}{l}\text { F: AATTAGCCGGTCATGGTG } \\
\text { R: GCTGGAGTGCCGTGGTAT }\end{array}$ & 124 \\
GAPDH & $\begin{array}{l}\text { F: ACCCAGAAGACTGTGGATGG } \\
\text { R: TTCAGCTCAGGGATGACCTT }\end{array}$ & 125 \\
& & \\
\hline
\end{tabular}

BRCA1, breast cancer type 1 susceptibility protein; bp, base pairs; F, forward; R, reverse.

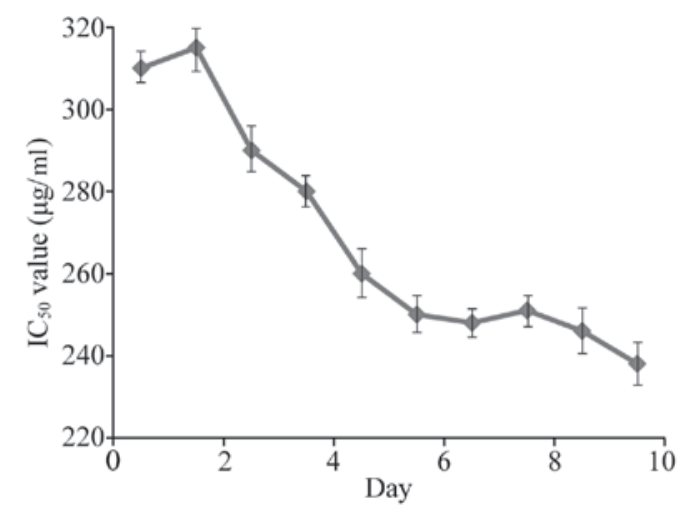

Figure 1. Analysis of the viability of HCT-8/V cells 6 days following the removal of vincristine. $\mathrm{IC}_{50}$, half-maximal inhibitory concentration.

containing 2,000 $\mathrm{ng} / \mathrm{ml} \mathrm{VCR}$ which was 12.7 times the concentration tolerated by the HCT- 8 cells. The HCT- 8 and HCT-8/V colon cancer cells were subsequently treated with different concentrations of VCR, and the $\mathrm{IC}_{50}$ of VCR in the HCT-8 and HCT-8/V cells was 13.56 and $165.49 \mu \mathrm{g} / \mathrm{ml}$, respectively (data not shown). The MTT assay results indicate that the resistance phenotype of the cells was stable 6 days following withdrawal of VCR supplementation in the culture medium (Fig. 1).

BRCA1 mRNA expression is increased in VCR-resistant colon cancer cells. Total RNA was isolated from the VCR-resistant and VCR-sensitive colon cancer cells, and the expression levels of BRCA1 in these cells was assessed using RT-qPCR analysis with gene-specific primers (Table I). The melting curves of BRCA1 and GAPDH amplification are illustrated in Fig. 2A and B, respectively. The relative expression of BRCA1 was significantly lower (10.72-fold) in VCR-sensitive HCT-8 cells compared with the VCR-resistant cells $(0.09333 \pm 0.01856$ vs. 1.0000 $\pm 0.07810 ; \mathrm{P}<0.01$; Fig. 2C).

BRCA1 protein expression is increased in VCR-resistant colon cancer cells. Total protein was extracted from the HCT-8 and HCT-8/V cells for western blot analysis. BRCA1 expression was normalized to that of the reference protein ( $\beta$-actin) to determine the relative expression levels. The expression of BRCA1 was significantly lower in the drug-sensitive cells 

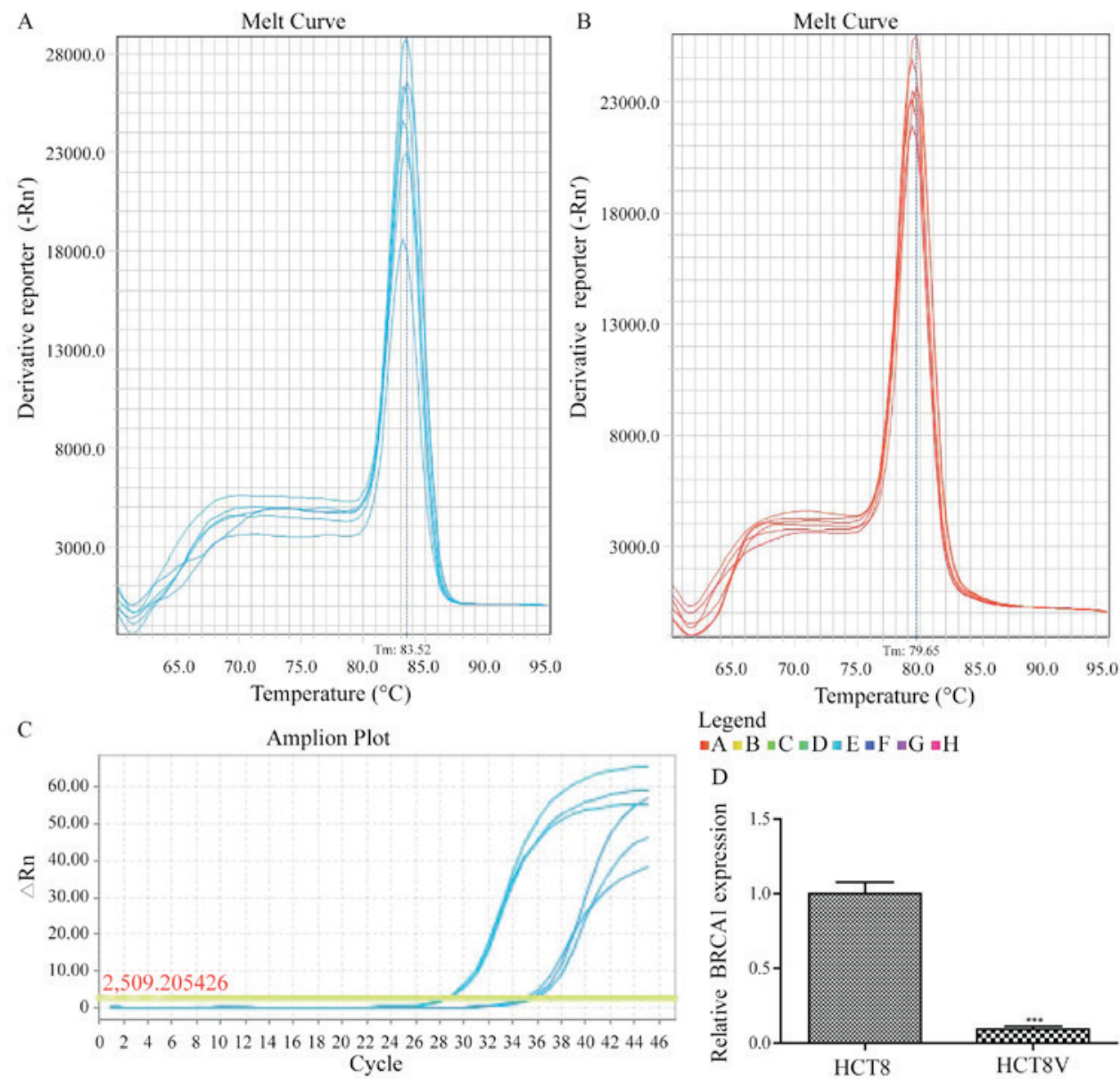

Figure 2. BRCA1 expression in HCT-8 and HCT-8/V cells was detected by reverse transcriptase quantitative-polymerase chain reaction analysis. Melt curve of (A) BRCA1 and (B) GAPDH. (C) Amplification plot and analysis of BRCA1 expression. The experiment was repeated three times. BRCA1, breast cancer type 1 susceptibility protein.
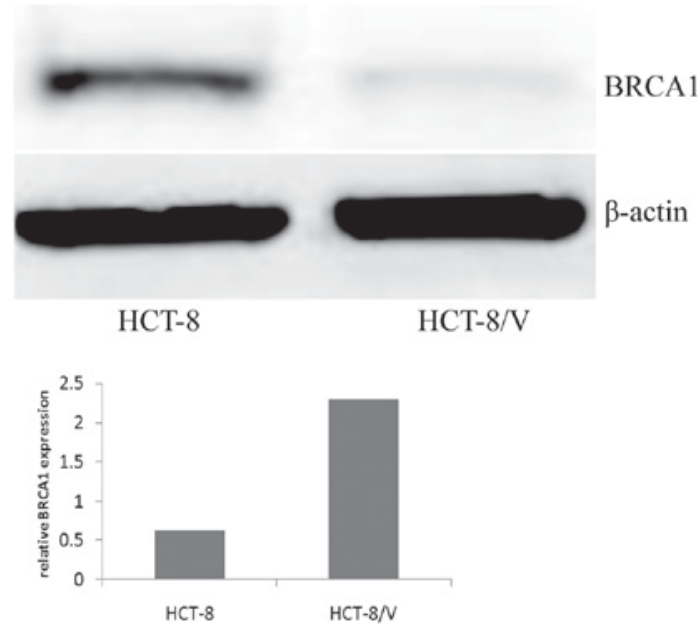

Figure 3. BRCA1 expression in HCT-8 and HCT-8/V cells was detected by western blot analysis. $\beta$-actin was used as a loading control. BRCA1, breast cancer type 1 susceptibility protein.

compared with their VCR-resistant counterparts. BRCA1 protein expression in the HCT-8/V cells $(2.2937 \pm 0.5421)$ was 3.68 times higher compared with that in the drug-sensitive cells (0.6233 $\pm 0.3654 ; \mathrm{P}<0.05$; Fig. 3$)$.

\section{Discussion}

VCR is widely used in the clinical treatment of leukemia, lung cancer and other malignant tumors; however, during VCR use, tumors gradually exhibit resistance to the drug (15-19). The molecular mechanism underlying VCR resistance is complex and involves a number of genes, including insulin-like growth factor-binding protein 7 and multidrug resistance protein 1, in addition to long non-coding RNA (20-22). In the present study, a VCR-resistant cell line (HCT-8/V) was established to explore the mechanism of drug resistance in colon cancer cells to VCR by gradually increasing the drug concentration during cell culture. The concentration of VCR tolerated by the HCT-8/V cells was 2,000 ng/ml, which was 12.7 times the concentration tolerated by the HCT- 8 cells.

Germline mutations in the BRCA1 and BRCA2 genes account for $5 \%$ of all breast cancers and $\sim 80 \%$ of families with these mutations suffer from hereditary breast cancer and ovarian cancer (23). Lohse et al (24) identified that BRCA1 and BRCA2 mutant xenografts were significantly more sensitive to cisplatin compared with the control, while the BRCA1 and BRCA2 wild type models exhibited sensitivity to gemcitabine but not to cisplatin. However, BRCA1 expression was significantly decreased in the HCT- 8 cells compared with in the drug-resistant cells. 
Following treatment with vinca alkaloids, including vincristine, tumor cells may acquire drug resistance in the following ways: Modifications to the action site of drugs, including tubulin sequence mutations or changes in the cytoskeletal protein (25); high expression of drug efflux pumps resulting in reduced intracellular drug concentrations (26); activation of the detoxification system by other non-toxic compounds (27); or inhibition of apoptotic signal transduction resulting in reduced apoptosis (28). The findings reported in the present study demonstrate that the drug resistance of colon cancer cells can increase the expression of BRCA1. Further investigation into VCR-resistance in these cells is required to improve understanding of the underlying molecular mechanisms of chemotherapeutic drug resistance in tumors.

\section{References}

1. Das V, Kalita J and Pal M: Predictive and prognostic biomarkers in colorectal cancer: A systematic review of recent advances and challenges. Biomed Pharmacother 87: 8-19, 2017.

2. Pabla B, Bissonnette M and Konda VJ: Colon cancer and the epidermal growth factor receptor: Current treatment paradigms, the importance of diet and the role of chemoprevention. World J Clin Oncol 6: 133-141, 2015.

3. Shekhar MP: Drug resistance: Challenges to effective therapy. Curr Cancer Drug Targets 11: 613-623, 2011.

4. Kimura M, Endo H, Inoue T, Nishino K, Uchida J, Kumagai T, Kukita Y, Kato K, Imamura F and Inoue M: Analysis of ERBB ligand-induced resistance mechanism to crizotinib by primary culture of lung adenocarcinoma with EML4-ALK fusion gene. J Thorac Oncol 10: 527-530, 2015

5. Zhang L, Ngo JA, Wetzel MD and Marchetti D: Heparanase mediates a novel mechanism in lapatinib-resistant brain metastatic breast cancer. Neoplasia 17: 101-113, 2015.

6. Borges S, Döppler HR and Storz P: A combination treatment with DNA methyltransferase inhibitors and suramin decreases invasiveness of breast cancer cells. Breast Cancer Res Treat 144: 79-91, 2014.

7. Ma J, Fang B, Zeng F, Ma C, Pang H, Cheng L, Shi Y, Wang H, Yin B, Xia J, et al: Down-regulation of miR-223 reverses epithelial-mesenchymal transition in gemcitabine-resistant pancreatic cancer cells. Oncotarget 6: 1740-1749, 2015.

8. Camplejohn RS: A critical review of the use of vincristine (VCR) as a tumour cell synchronizing agent in cancer therapy. Cell Tissue Kinet 13: 327-335, 1980.

9. Antoniou A, Pharoah PD, Narod S, Risch HA, Eyfjord JE, Hopper JL, Loman N, Olsson H, Johannsson O, Borg A, et al: Average risks of breast and ovarian cancer associated with BRCA1 or BRCA2 mutations detected in case Series unselected for family history: A combined analysis of 22 studies. Am J Hum Genet 72: 1117-1130, 2003.

10. Singh KK, Shukla PC, Quan A, Al-Omran M, Lovren F, Pan Y, Brezden-Masley C, Ingram AJ, Stanford WL, Teoh H and Verma S: BRCA1 is a novel target to improve endothelial dysfunction and retard atherosclerosis. J Thorac Cardiovasc Surg 146: 949-960. e4, 2013.

11. Phelan CM, Iqbal J, Lynch HT, Lubinski J, Gronwald J, Moller P, Ghadirian P, Foulkes WD, Armel S, Eisen A, et al: Incidence of colorectal cancer in BRCA1 and BRCA2 mutation carriers: Results from a follow-up study. Br J Cancer 110: 530-534, 2014.

12. Wang TY, Zhang QQ, Zhang X, Sun QL, Zhao CP and Wang XY: The effect of recombinant lentiviral vector encoding miR-145 on human esophageal cancer cells. Tumour Biol 36: 9733-9738, 2015.

13. Zhang JH, Du AL, Wang L, Wang XY, Gao JH and Wang TY: Episomal lentiviral vector-mediated miR-145 overexpression inhibits proliferation and induces apoptosis of human esophageal carcinomas cells. Recent Pat Anticancer Drug Discov 11: 453-460, 2016

14. Dong WH, Wang TY, Wang F and Zhang JH: Simple, time-saving dye staining of proteins for sodium dodecyl sulfate-polyacrylamide gel electrophoresis using Coomassie blue. PLoS One 6: e22394, 2011.
15. Chao MW, Lai MJ, Liou JP, Chang YL, Wang JC, Pan SL and Teng CM: The synergic effect of vincristine and vorinostat in leukemia in vitro and in vivo. J Hematol Oncol 8: 82, 2015.

16. Jung SO, Kim SY, Kim JO, Jung SS, Park HS, Moon JY, Kim SM and Lee JE: Promising effects of 3rd line cyclophosphamide, adriamycin and vincristine (CAV) and 4th line ifosfamide and carboplatin chemotherapy in refractory small cell lung cancer. Thorac Cancer 6: 659-663, 2015.

17. Xu Y and Qiu L: Nonspecifically enhanced therapeutic effects of vincristine on multidrug-resistant cancers when coencapsulated with quinine in liposomes. Int J Nanomedicine 10: 4225-4237, 2015.

18. Qiu JG, Zhang YJ, Li Y, Zhao JM, Zhang WJ, Jiang QW, Mei XL, Xue YQ, Qin WM, Yang Y, et al: Trametinib modulates cancer multidrug resistance by targeting $\mathrm{ABCB} 1$ transporter. Oncotarget 6: 15494-15509, 2015.

19. Tsubaki M, Takeda T, Ogawa N, Sakamoto K, Shimaoka H, Fujita A, Itoh T, Imano M, Ishizaka T, Satou T and Nishida S: Overexpression of survivin via activation of ERK1/2, Akt, and $\mathrm{NF}-\kappa \mathrm{B}$ plays a central role invincristine resistance in multiple myeloma cells. Leuk Res 39: 445-452, 2015.

20. Bartram I, Erben U, Ortiz-Tanchez J, Blunert K, Schlee C, Neumann M, Heesch S and Baldus CD: Inhibition of IGF1-R overcomes IGFBP7-induced chemotherapy resistance in T-ALL. BMC Cancer 15: 663, 2015

21. Tivnan A, Zakaria Z, O'Leary C, Kögel D, Pokorny JL, Sarkaria JN and Prehn JH: Inhibition of multidrug resistance protein 1 (MRP1) improves chemotherapy drug response in primary and recurrent glioblastoma multiforme. Front Neurosci 9: 218, 2015.

22. Sun QL, Zhao CP, Wang TY, Hao XB, Wang XY, Zhang X and Li YC: Expression profile analysis of long non-coding RNA associated with vincristine resistance in colon cancer cells by next-generation sequencing. Gene 572: 79-86, 2015.

23. Elia AE and Elledge SJ: BRCA1 as tumor suppressor: Lord without its RING? Breast Cancer Res 14: 306, 2012.

24. Lohse I, Borgida A, Cao P, Cheung M, Pintilie M, Bianco T, Holter S, Ibrahimov E, Kumareswaran R, Bristow RG, et al: BRCA1 and BRCA2 mutations sensitize to chemotherapy in patient-derived pancreatic cancer xenografts. Br J Cancer 113: 425-432, 2015.

25. Dumontet C, Jaffrezou JP, Tsuchiya E, Duran GE, Chen G, Derry WB, Wilson L, Jordan MA and Sikic BI: Resistance to microtubule-targeted cytotoxins in a K562 leukemia cell variant associated with altered tubulin expression and polymerization. Bull Cancer 91: E81-E112, 2004.

26. Cousein E, Barthélémy C, Poullain S, Simon N, Lestavel S, Williame V, Joiris E, Danel C, Clavey V, Brossard D, et al: P-glycoprotein and cytochrome P450 3A4 involvement in risperidone transport using an in vitro $\mathrm{Caco}-2 / \mathrm{TC} 7$ model and an in vivo model. Prog Neuropsychopharmacol Biol Psychiatry 31: 878-886, 2007.

27. Liu CL, Lim YP and $\mathrm{Hu}$ ML: Fucoxanthin attenuates rifampin-induced cytochrome P450 3A4 (CYP3A4) and multiple drug resistance 1 (MDR1) gene expression through pregnane $\mathrm{X}$ receptor (PXR)-mediated pathways in human hepatoma HepG2 and colon adenocarcinoma LS174T cells. Mar Drugs 10: 242-257, 2012.

28. Yu CJ, Ou JH, Wang ML, Jialielihan N and Liu YH: Elevated survivin mediated multidrug resistance and reduced apoptosis in breast cancer stemcells. J BUON 20: 1287-1294, 2015. 